University of Nebraska - Lincoln

DigitalCommons@University of Nebraska - Lincoln

Fractured-Aquifer Hydrogeology from Geophysical Logs:

Brunswick Group and Lockatong Formation, Pennsylvania

Roger H. Morin

Denver Federal Center, roger.morin49@gmail.com

Lisa A. Senior

U.S. Geological Survey, Malvern

Edward R. Decker

University of Maine

Follow this and additional works at: https://digitalcommons.unl.edu/usgsstaffpub

Part of the Earth Sciences Commons

Morin, Roger H.; Senior, Lisa A.; and Decker, Edward R., "Fractured-Aquifer Hydrogeology from Geophysical Logs: Brunswick Group and Lockatong Formation, Pennsylvania" (2000). USGS Staff -- Published Research. 352.

https://digitalcommons.unl.edu/usgsstaffpub/352

This Article is brought to you for free and open access by the US Geological Survey at DigitalCommons@University of Nebraska - Lincoln. It has been accepted for inclusion in USGS Staff -- Published Research by an authorized administrator of DigitalCommons@University of Nebraska - Lincoln. 


\title{
Fractured-Aquifer Hydrogeology from Geophysical Logs: Brunswick Group and Lockatong Formation, Pennsylvania
}

\author{
by Roger H. Morin a, Lisa A. Senior ${ }^{b}$, and Edward R. Decker ${ }^{c}$
}

\begin{abstract}
The Brunswick Group and the underlying Lockatong Formation are composed of lithified Mesozoic sediments that constitute part of the Newark Basin in southeastern Pennsylvania. These fractured rocks form an important regional aquifer that consists of gradational sequences of shale, siltstone, and sandstone, with fluid transport occurring primarily in fractures. An extensive suite of geophysical logs was obtained in seven wells located at the borough of Lansdale, Pennsylvania, in order to better characterize the areal hydrogeologic system and provide guidelines for the refinement of numerical ground water models. Six of the seven wells are approximately $120 \mathrm{~m}$ deep and the seventh extends to a depth of $335 \mathrm{~m}$. Temperature, fluid conductivity, and flowmeter logs are used to locate zones of fluid exchange and to quantify transmissivities. Electrical resistivity and natural gamma logs together yield detailed stratigraphic information, and digital acoustic televiewer data provide magnetically oriented images of the borehole wall from which almost 900 fractures are identified.

Analyses of the geophysical data indicate that the aquifer penetrated by the deep well can be separated into two distinct structural domains, which may, in turn, reflect different mechanical responses to basin extension by different sedimentary units:

1. In the shallow zone (above $125 \mathrm{~m}$ ), the dominant fracture population consists of gently dipping bedding plane partings that strike $\mathrm{N46}^{\circ} \mathrm{E}$ and dip to the northwest at about 11 degrees. Fluid flow is concentrated in the upper $80 \mathrm{~m}$ along these subhorizontal fractures, with transmissivities rapidly diminishing in magnitude with depth.

2. The zone below $125 \mathrm{~m}$ marks the appearance of numerous high-angle fractures that are orthogonal to the bedding planes, striking parallel but dipping steeply southeast at 77 degrees.

This secondary set of fractures is associated with a fairly thick (approximately $60 \mathrm{~m}$ ) high-resistivity, low-transmissivity sandstone unit that is abruptly terminated by a thin shale bed at a depth of $190 \mathrm{~m}$. This lower contact effectively delineates the aquifer's vertical extent at this location because no detectable evidence of ground water movement is found below it. Thus, fluid flow is controlled by fractures, but fracture type and orientation are related to lithology. Finally, a transient thermal-conduction model is successfully applied to simulate observed temperature logs, thereby confirming the effects of ground-surface warming that occurred in the area as a result of urbanization at the turn of the century. The systematic warming of the upper $120 \mathrm{~m}$ has increased the transmissivity of this aquifer by almost $10 \%$, simply due to changes in fluid viscosity and density.
\end{abstract}

\section{Introduction}

An extensive discussion by Long et al. (1996) of research efforts directed toward understanding fluid flow through fractured rocks outlines the variety and sophistication of scientific approaches being pursued and underscores the complexity of the topic. Laboratory-scale studies, field-scale investigations, and numerical models have all contributed, in varying degrees, to the present knowledge of the transport properties of heterogeneous networks of fractures in the earth.

Numerous field studies (e.g., Williams et al. 1993; Stone et al. 1996) have demonstrated the value and utility of using borehole geophysical logs to directly determine the hydrogeologic characteristics of ground water systems. Geophysical logs from multiple wells yield in situ measurements of fluid and rock properties as func-

"U.S. Geological Survey, Denver, CO 80225; (303) 236-5915; fax (303) 236-5968. E-mail: rhmorin@usgs.gov

bU.S. Geological Survey, Malvern, PA 19355; (610) 647-9008; fax (610) 647-4594. E-mail: lasenior@usgs.gov

University of Maine, Orono, ME 04473; (207) 581-2158; fax (207)

581-2144. E-mail: eddecker@maine.maine.edu

Received March 1999, accepted October 1999 tions of depth, from which generalized flow patterns can be inferred and stratigraphic correlations can be constructed. The application of these types of field techniques to sedimentary basins can ease considerably the complex task of characterizing the transport properties of fractured rocks, because factors such as depositional environment, lithologic variability, and stress history may be manifested in the logs as consistent trends and patterns or as anomalous responses. Examination of such information within a regional context can improve the basic understanding of individual hydrologic systems and also help refine numerical models of these bedrock aquifers.

In this paper, we report on the results of a hydrogeologic field study based on a systematic collection of geophysical logs obtained from seven wells that penetrate rocks of the Newark Basin in southeastern Pennsylvania. The field measurements provide fundamental information on predominant fracture populations, lithostratigraphic variations, and the spatial distribution of transmissivity across the site. The method and approach are similar to those conducted by Morin et al. (1997) at another study area in the Newark Basin located in neighboring New Jersey. However, important distinctions between the results from the two sites illustrate how subtle variations in lithostratigraphy can significantly influence local hydrogeologic properties. The thermal effects of regional urban- 


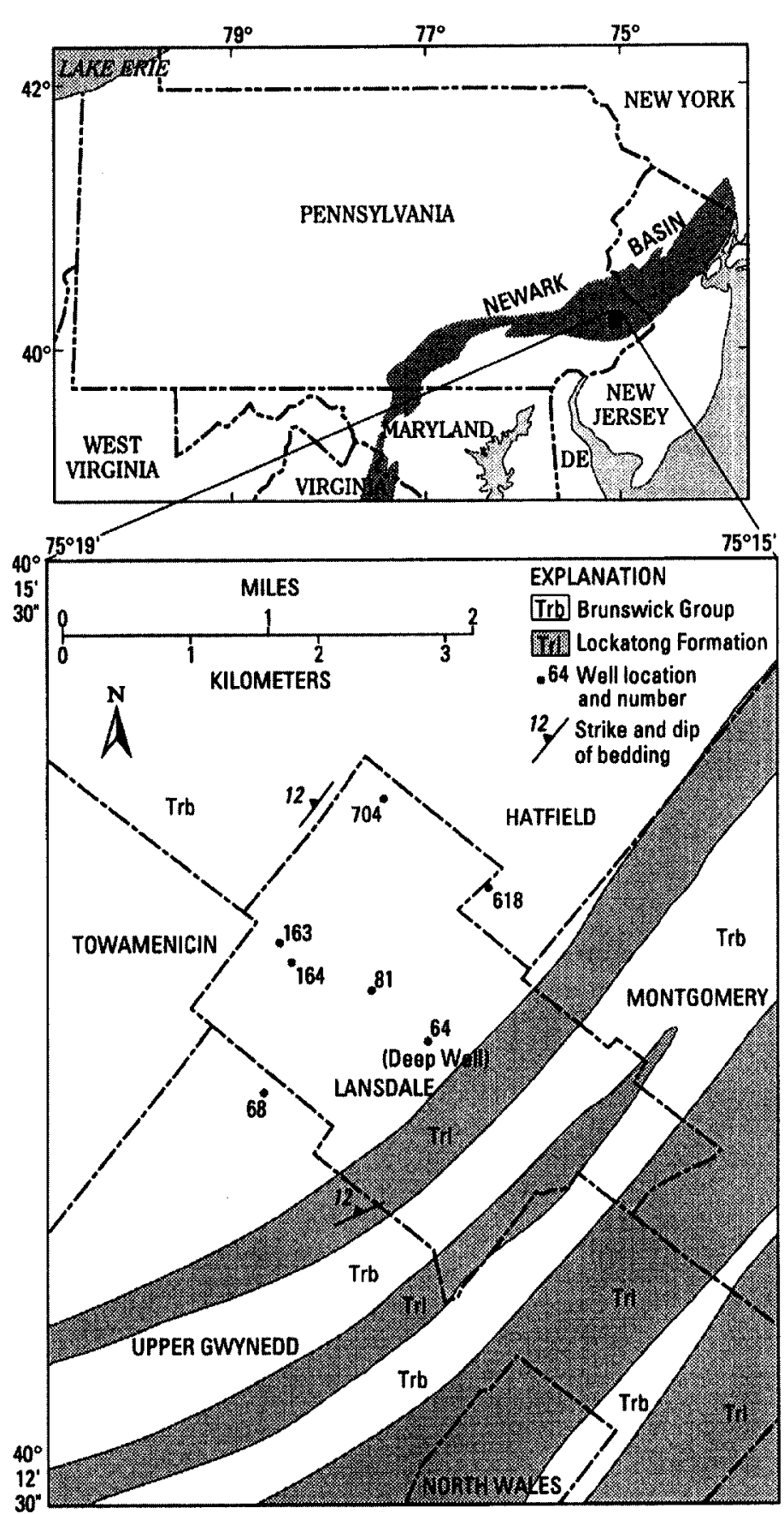

Figure 1. Locations of study site and test wells (adapted from Longwill and Wood 1965).

ization at the turn of the century are also identified at this Pennsylvania site, and some possible implications of surficial warming on the behavior of the local hydrologic system are discussed

\section{Hydrogeologic Setting}

The study site is located at the borough of Lansdale, Pennsylvania, approximately $18 \mathrm{~km}$ north of Philadelphia (Figure 1). This area is situated in the Newark Basin, an elongate ( 210 by $55 \mathrm{~km}$ ), northeast-southwest-trending trough filled with late Triassic and early Jurassic fluvial and lacustrine sediments (Olsen 1980; Parker et al. 1988; Houghton 1990). The sedimentary rocks of the Newark Basin are similar to units in about 25 other inland rift basins along the northeast coast of North America; these include important regional aquifers such as the Brunswick Group and the
Passaic Formation (Froelich and Robinson 1988).

The study area is underlain by rock units of the lower Brunswick Group, which in turn overlies the Lockatong Formation. Both of these formations consist of interlayered sequences of siltstone, sandstone, and shale (Lyttle and Epstein 1987; Olsen 1988). Rock units generally strike northeast-southwest and dip northwesterly at about 12 degrees (Longwill and Wood 1965; Figure 1), similar to the general trend observed in much of the Newark Basin. However, the homoclinal structure is interrupted by intrabasin faults and warped by transverse folds (Schlische 1992). The nearby Chalfont Fault, approximately $8 \mathrm{~km}$ to the north, is a left-lateral, intrabasinal transfer fault that strikes northwest-southeast (Schlische 1992), but appears to have no effect on fracture orientations in the Lansdale wells. Linear ridges expressed in the surface topography reflect the northeast-southwest trend (strike) of more resistant, coarser-grained rock layers and coincide with the street layout in the borough. Primary porosity is low in these lithified rocks and fluid transport occurs predominantly in fractures. The layered sedimentary rocks form an aquifer under confined or semiconfined conditions that is recharged by precipitation through surficial soil and saprolite. Depth to bedrock is commonly less than $6 \mathrm{~m}$.

The borough of Lansdale has been a center for manufacturing and small industry since the early 1900s, and water supply wells in the area have shown evidence of contamination by low concentrations of organic solvents (CH2M Hill Inc. 1991). The area was designated as a U.S. Environmental Protection Agency (U.S. EPA) Superfund site in 1989 and an extensive effort is currently under way to characterize the local hydrogeologic setting through the use of a variety of complementary scientific approaches. Surface and borehole geophysics, aquifer tests, packer experiments, surface mapping, and numerical modeling are all components of this ongoing work.

\begin{tabular}{|c|c|c|c|c|}
\hline \multicolumn{5}{|c|}{$\begin{array}{c}\text { Table } 1 \\
\text { General Well Information }\end{array}$} \\
\hline $\begin{array}{l}\text { Well } \\
\text { Number }\end{array}$ & $\begin{array}{l}\text { Well depth } \\
\text { (m) }\end{array}$ & $\begin{array}{l}\text { Well diameter } \\
\qquad(\mathrm{cm})\end{array}$ & $\begin{array}{c}\text { Year } \\
\text { Drilled }\end{array}$ & $\begin{array}{c}\text { Transmissivity } \\
\left(\mathbf{m}^{2 / d a y}\right)\end{array}$ \\
\hline 64 & 335 & 20 & 1910 & 9 \\
\hline 68 & 152 & ${ }^{a} 36,25,20$ & 1927 & - \\
\hline 81 & 106 & 20 & 1936 & - \\
\hline 163 & 97 & 20 & 1947 & 83 \\
\hline 164 & 123 & 20 & 1947 & 36 \\
\hline 618 & 120 & 15 & 1958 & 4 \\
\hline 704 & 121 & 25 & 1961 & 71 \\
\hline
\end{tabular}

\section{Geophysical Log Analysis}

As part of this multidisciplinary investigation, seven wells within the boundaries of Lansdale were selected for detailed geophysical logging activities; their locations are shown in Figure 1 and additional details regarding their construction are listed in Table 1. These wells were specifically chosen to delineate transects across the site for spatial control, and to complement the inventory of geophysical logs previously collected as part of a general site-surveillance plan (Conger 1999). All seven wells were installed using hammer-driven methods from 1910 to the early 1960s as industrialization and urbanization placed additional demands on the local 


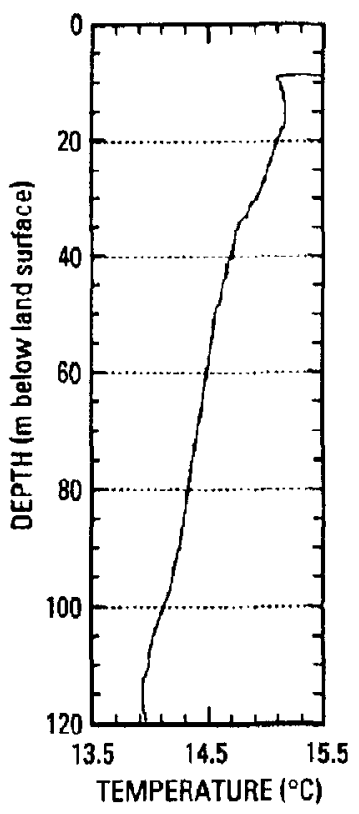

(b)

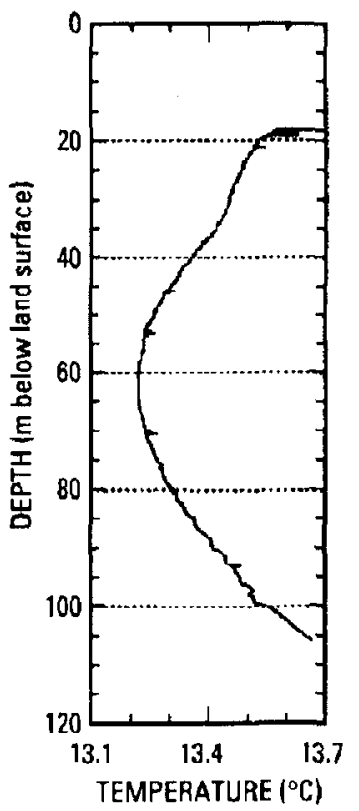

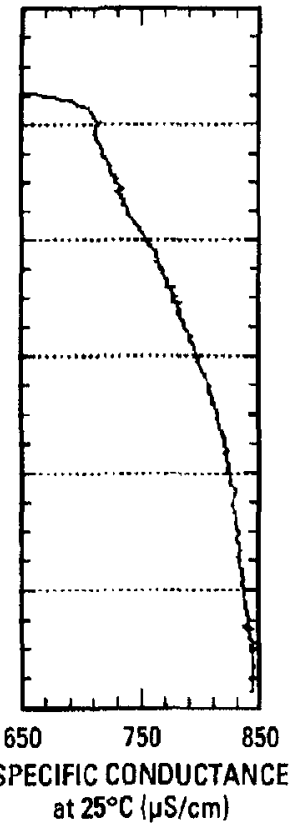

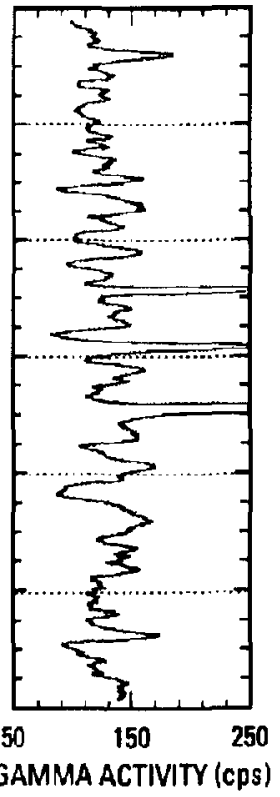

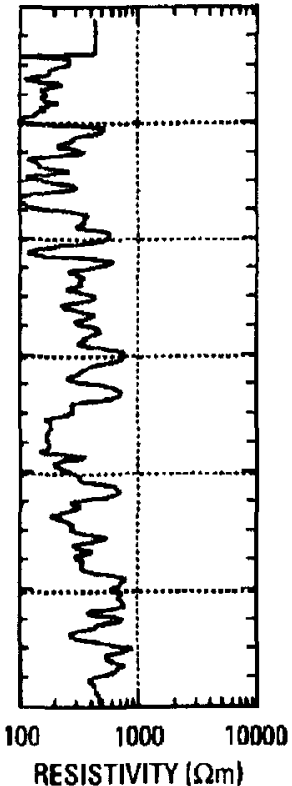

RESISTIVITY $(\Omega \mathrm{m})$

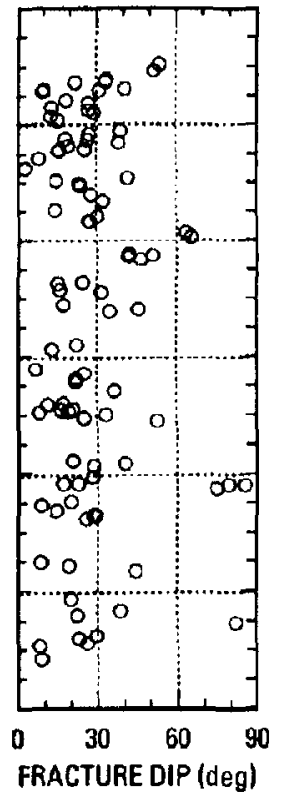

FRACTURE DIP (deg)

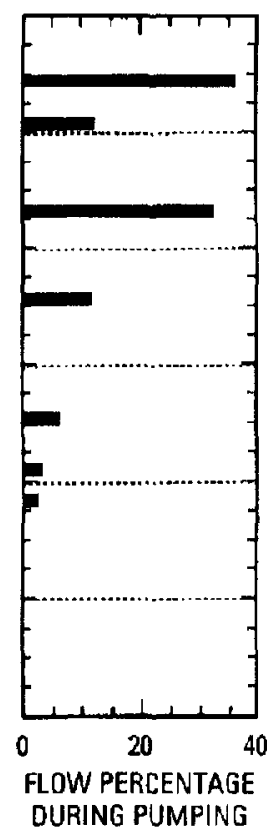

WELL 618

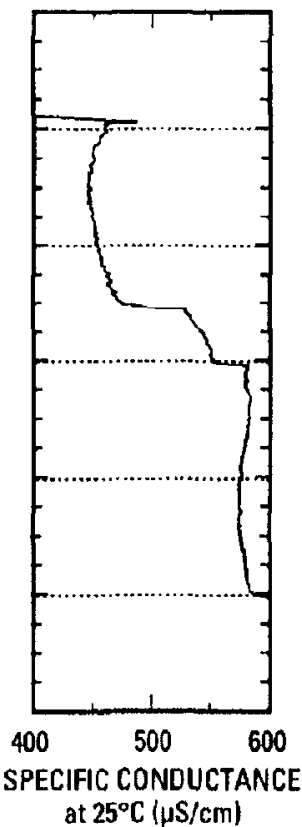

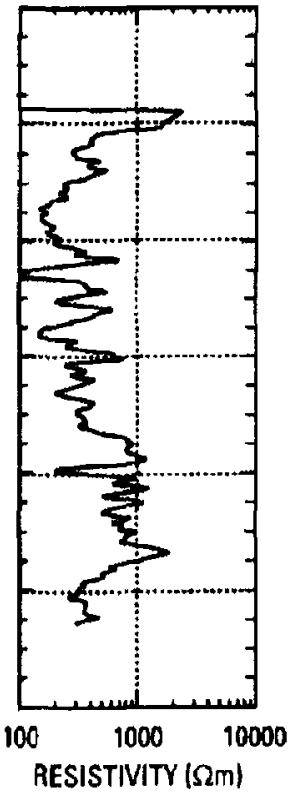

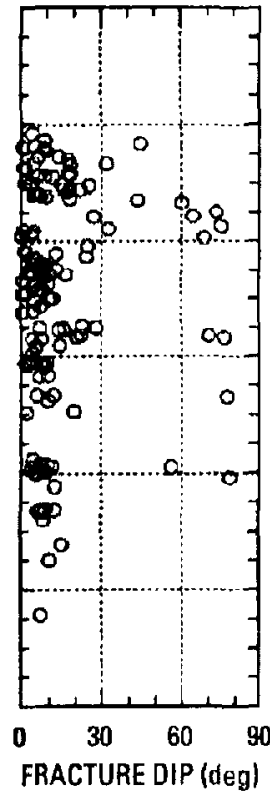

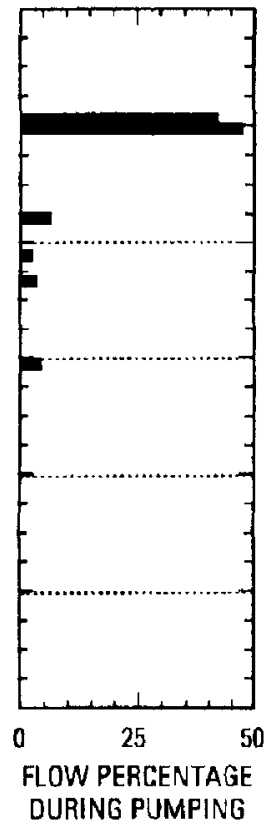

Figure 2. Composites of selected logs from (a) well 618 and (b) well 164.

water supply. Only a few meters of surface casing exist in each well; six are approximately $120 \mathrm{~m}$ deep and one (well 64) extends to a depth of $335 \mathrm{~m}$. Abandoned several years ago, these wells now afford important access to the subsurface for detailed examination of the local ground water system. Geophysical logs obtained from the six shallow wells yielded important information regarding local hydrogeologic characteristics and also presented an opportunity to compare results with those derived from similar geophysical studies conducted in shallow wells ( $<62 \mathrm{~m}$ depth) at another location in the Newark Basin (Morin et al. 1997). Additional insight gleaned from the deep-well logs was invaluable in contributing toward a more complete understanding of this aquifer.

The suite of geophysical tools deployed in this field study consisted of caliper, temperature, fluid conductivity, formation electrical resistivity, natural gamma activity, acoustic borehole televiewer (Zemanek et al. 1970), and heat-pulse flowmeter (Hess 1986) under ambient and pumping conditions. The televiewer provides a magnetically oriented image of the borehole wall generated from the amplitudes and travel times of reflected acoustic pulses. The digital televiewer used in this study represents an important technological advancement over the older analog models. The ability to magnify and enhance wellbore images improved our facility to identify discrete fractures and recognize textures. The high resolution heat-pulse flowmeter uses the principle of temperature tag-trace to measure vertical fluid velocities as slow as about $2 \mathrm{~cm} / \mathrm{min}$. This tool was used to determine the vertical distribution of fluid flow dur- 
ing pumping in order to locate productive zones and to quantify transmissivity as a function of depth (Morin et al. 1988; Molz et al. 1989). Pumping tests using this technique were successfully performed in five of the seven wells (Table 1).

The temperature and conductance logs reflect the variations in fluid properties with depth and may provide evidence for fluid movement (Drury et al. 1984; Drury 1989). Sudden shifts in temperature or conductance are indicative of zones of fluid exchange between the borehole and the surrounding formation, possibly resulting in a stratified fluid column if vertical mixing is negligible. When there is no fluid movement in the well to disturb the natural thermal gradient and heat transfer is predominantly conductive, the temperature log projects the natural geothermal gradient (e.g., Roy et al. 1968). Subtle changes in the slope of this profile reflect variations in the thermal conductivity of the formation (e.g., Conaway and Beck 1977).

The natural gamma and the electrical resistivity logs respond primarily to lithologic properties. High gamma activity is typically associated with the presence of fine-grained units that tend to accumulate radioisotopes through adsorption and ion-exchange processes. Conversely, coarser-grained sandstone/conglomerate units generally have low gamma activity. However, at some locations in the Newark Basin, arkosic sandstone units containing potassium feldspar (Weddle and Hubert 1983) may also generate high gamma counts. Measurements of formation electrical resistivity are primarily affected by pore water specific conductance, porosity, and grain size (Archie 1942). Low-porosity, coarse-grained sandstones typically exhibit higher resistivities than do finer grained deposits that are more efficient electrical conductors. The gamma and the electric logs often serve as complementary lithologic indicators, particularly when potassium feldspars are not present, and can be effectively used for stratigraphic correlation among wells.

\section{Shallow Wells}

Composites of selected logs for two of the six shallow wells (wells 618 and 164) are presented in Figure 2. Values of fluid conductivity have been converted to specific conductance standardized to $25^{\circ} \mathrm{C}$. Individual fractures were identified from the wellbore images generated by the acoustic televiewer, and their dips and locations are included in the composites. Flowmeter measurements were conducted during pumping to locate zones of fluid exchange and these data are presented as a percentage of the total pumping rate measured at the surface. Pumping rates ranged from 4 to $15 \mathrm{~L} / \mathrm{min}$ and drawdowns were continuously monitored in order to assign a transmissivity value to each of these zones (Molz et al. 1989).

Flowmeter data indicate that most of the fluid being pumped out of each well originates within the top few tens of meters and that, though minor fluid exchange may persist to depths of $80 \mathrm{~m}$ or more, transmissivity decreases markedly with depth. Values of transmissivity integrated over the entire depth of each well range from 4 to $83 \mathrm{~m}^{2} /$ day (Table 1) and are consistent with results recently presented by Goode and Senior (1998). These investigators conducted an extensive review of aquifer tests for the Lansdale area and report that most transmissivities generally lie between 10 and $100 \mathrm{~m}^{2} /$ day.

The distinct spikes in gamma activity, depicted in units of counts per second (cps), correspond to shale beds that occur intermittently throughout the formation and that occasionally delineate a permeable lithologic contact as seen in the flow log. Coincident traces that roughly mirror each other emerge from

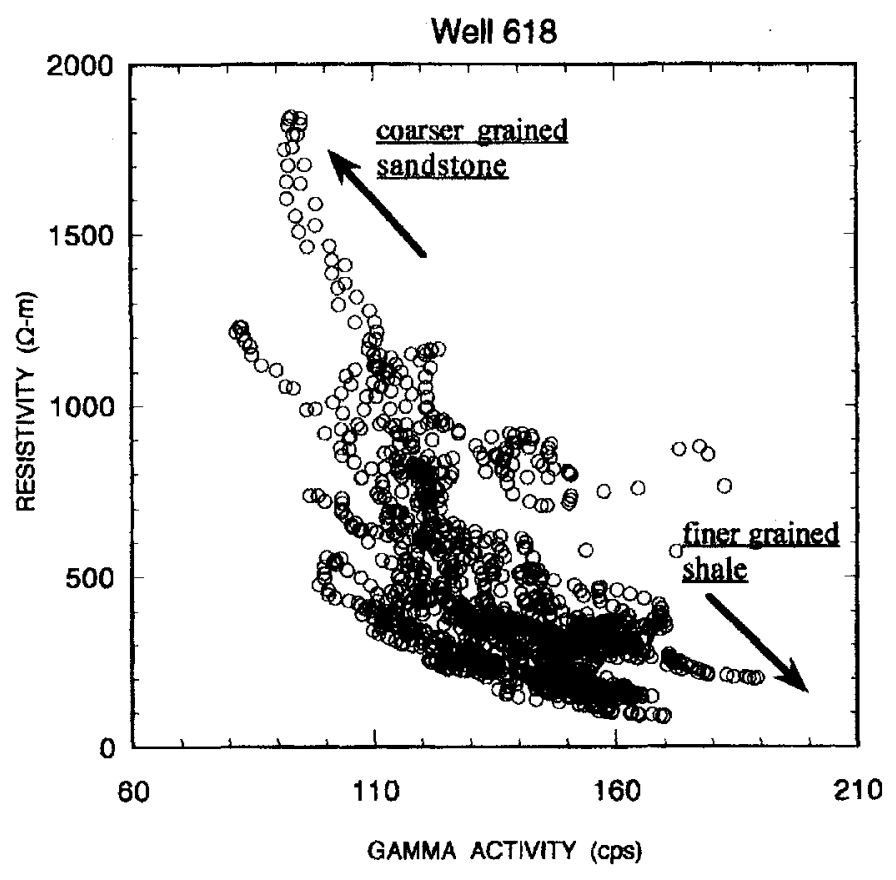

Figure 3. Correlation of natural gamma and resistivity logs from well 618.

visual inspection of the gamma and resistivity logs, indicating a possible inverse relation between these two parameters; high resistivity zones generally correspond to low gamma intervals and vice versa. A crossplot of these two logs for well 618 (Figure 3), where the shale spikes have been eliminated for clarity, confirms this interdependence. Coarse-grained sandstones appear as zones of high electrical resistivity and low gamma activity, whereas finegrained siltstones and shales generate high gamma counts but low resistivities. The variations in the gamma and resistivity logs shown in Figure 2 can be carefully dissected to identify fine-scale lithologic sequences. Stone et al. (1996) performed similar analyses with logs from deposits in the Hartford Basin, another of the numerous Mesozoic extensional basins located along the eastern seaboard.

At a nearby site in New Jersey, also situated in the Newark Basin, Morin et al. (1997) presented results of similar geophysical logging activities. This investigation was unsuccessful in identifying a clear lithologic connection between gamma activity and electrical resistivity because the gamma logs apparently contained superimposed "noise" produced by the ubiquitous presence of potassium feldspars. This additional variable in the log-interpretation scheme meant that high gamma activity could be equated to coarse-grained, high-resistivity sediments as well as to the conventional low-resistivity siltstones and shales. Consequently, there was a substantial deterioration in any obvious correspondence between the two parameters. The clear correlation between gamma counts and resistivity for well 618 in Lansdale (Figure 3) indicates that, unlike conditions at the New Jersey site, potassium feldspars are probably not prevalent in this area.

Planar features such as high-angle fractures, beds, contacts between beds, and bedding-plane partings were identified from the digital televiewer images and correlated with fluid-property logs to distinguish permeable features from the general fracture population. Most of the 700 features detected in the upper $125 \mathrm{~m}$ of the seven wells at this site are gently dipping, as illustrated by the series of dip data shown in Figure 2. These occur along lithologic contacts and are associated with bedding planes and partings. Magnetically 

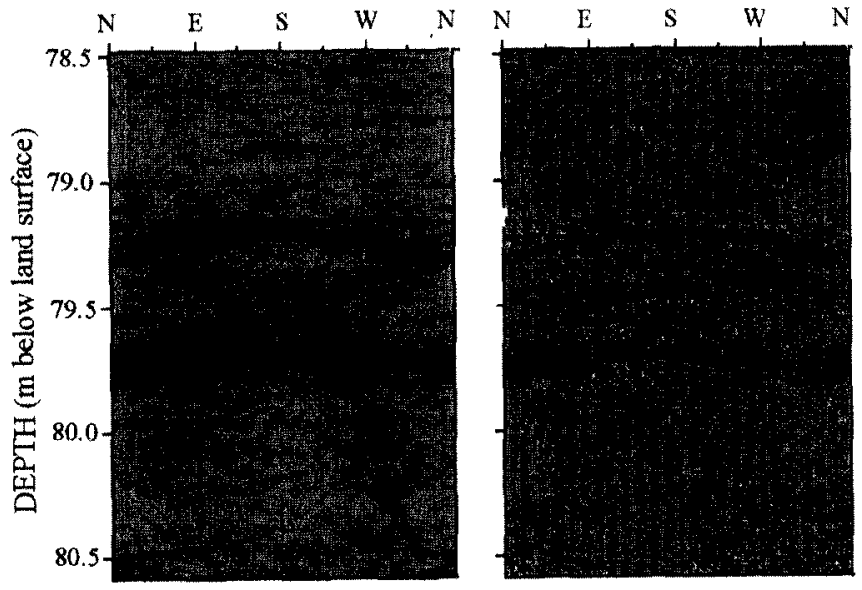

(a)

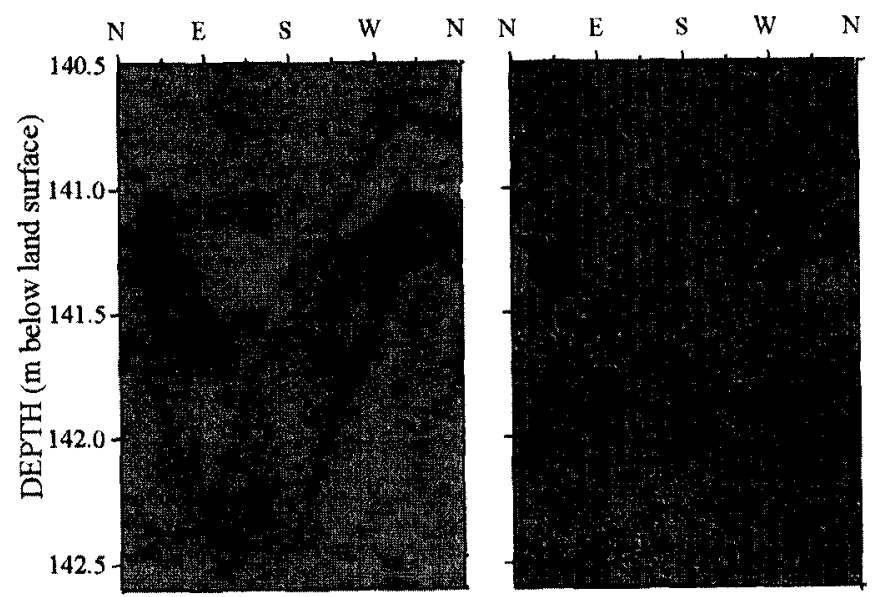

(b)

Figure 4. Digital, magnetically oriented images of the borehole wall (well 64) generated from the acoustic televiewer. Ieft panels are developed from acoustic amplitude data; right panels from acoustic travel-time data. Planar views depict (a) shallow dipping beddingplane partings and (b) high-angle fractures.

\begin{tabular}{|c|c|c|c|c|}
\hline \multicolumn{5}{|c|}{$\begin{array}{c}\text { Table } 2 \\
\text { Fracture Statistics Computed from Bingham Axial } \\
\text { Distribution Analysis }\end{array}$} \\
\hline \multirow{2}{*}{$\begin{array}{l}\text { Depth } \\
\text { Interval }\end{array}$} & \multirow{2}{*}{$\begin{array}{l}\text { Number of } \\
\text { Fractures }\end{array}$} & \multirow{2}{*}{$\begin{array}{c}\text { Eigenvalue } \\
\lambda\end{array}$} & \multicolumn{2}{|c|}{ Eigenvector } \\
\hline & & & Strike & Dip \\
\hline \multirow[t]{3}{*}{ Above $125 \mathrm{~m}$} & 700 & .802 & $\mathrm{~N} 45.8^{\circ} \mathrm{E}$ & $10.5^{\circ} \mathrm{NW}$ \\
\hline & & .119 & $N 50.3^{\circ} \mathrm{E}$ & $79.5^{\circ} \mathrm{SE}$ \\
\hline & & .080 & $\mathrm{~N} 39.8^{\circ} \mathrm{W}$ & $78.3^{\circ} \mathrm{NE}$ \\
\hline \multirow[t]{3}{*}{ Below $125 \mathrm{~m}$} & 180 & .596 & $\mathrm{~N} 43.3^{\circ} \mathrm{E}$ & $12.7^{\circ} \mathrm{NW}$ \\
\hline & & .364 & $\mathrm{~N} 46.9^{\circ} \mathrm{E}$ & $77.4^{\circ} \mathrm{SE}$ \\
\hline & & .040 & $\mathrm{~N} 43.4^{\circ} \mathrm{W}$ & $79.2^{\circ} \mathrm{NE}$ \\
\hline
\end{tabular}

oriented televiewer images of one such fracture is shown in Figure $4 a$, where digital acoustic amplitude (left panel) and acoustic travel time (right panel) data from a cylindrical borehole are projected as a planar, "unwrapped" view of the well. Nonhorizontal fractures that intersect the well appear as sinusoids in this figure, with amplitude being proportional to dip angle.

Rosette and lower-hemisphere, equal-area stereographic diagrams of fracture orientations plotted for all seven wells (six shallow wells and top $125 \mathrm{~m}$ of deep well) display a predominant northeast-southwest strike direction (Figure 5). This orientation

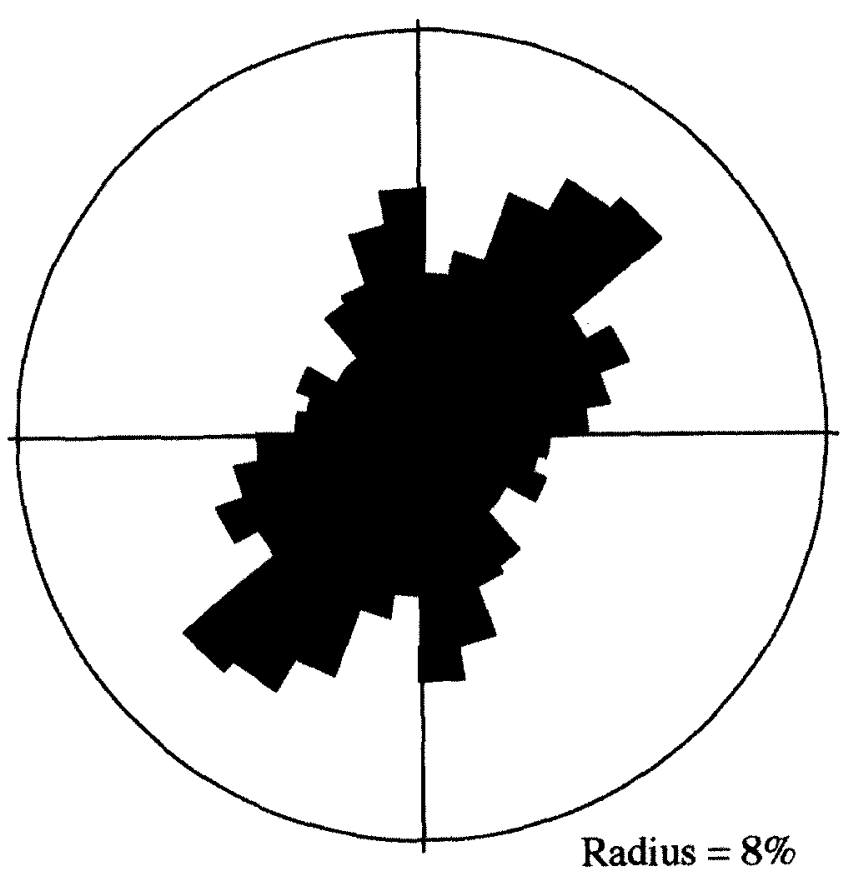

\section{all fractures above $125 \mathrm{~m}$}

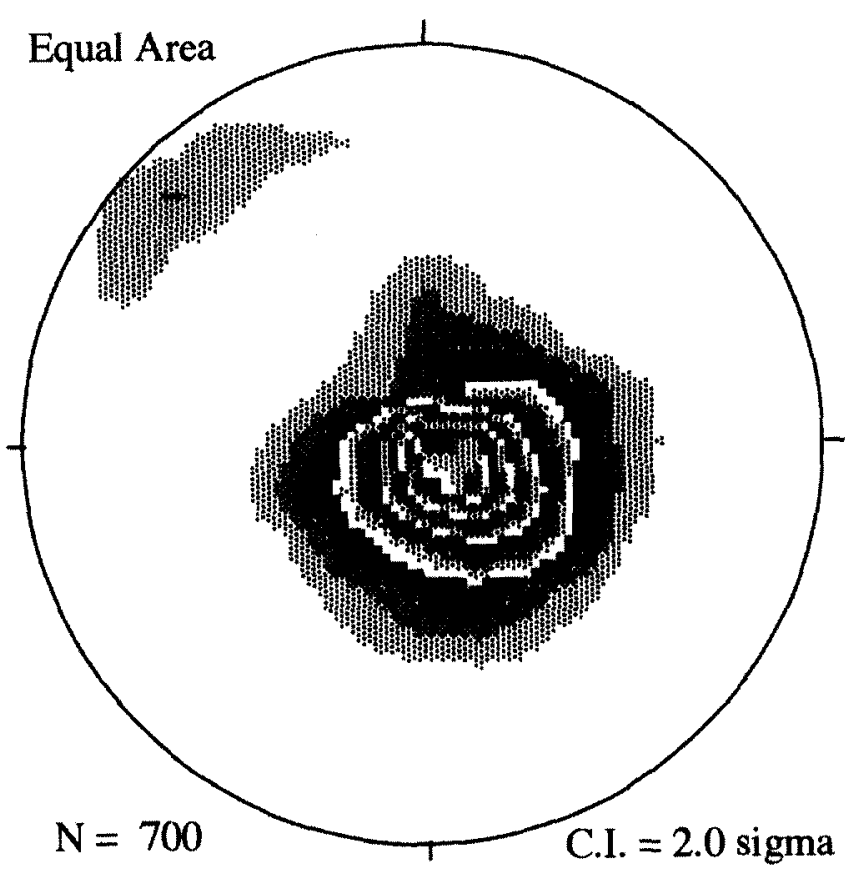

Figure 5. Rosette and equal-area stereographic diagrams representing fracture orientations in all seven wells above $125 \mathrm{~m}(\mathrm{~N}=$ number of fractures; C.I. = contour interval).

reflects the topographic surface expression of strike ridges present across the study area (Figure 1). Results of statistical analyses of fracture orientations computed by means of a Bingham axial distribution (Mardia 1972; Fisher et al. 1987) are presented in Table 2. The magnitudes of the eigenvalues, $\lambda$, and eigenvectors are listed, where the value of $\lambda$ is normalized to 1.0 and is considered to be a measure of the relative concentration of poles associated with a statistically significant fracture set. The eigenvector describes the orientation of a representative fracture plane within that set. For all fractures detected above $125 \mathrm{~m}$, one fracture population with a strike of $\mathrm{N} 46^{\circ} \mathrm{E}$ and a dip of about 11 degrees to the northwest is domi- 

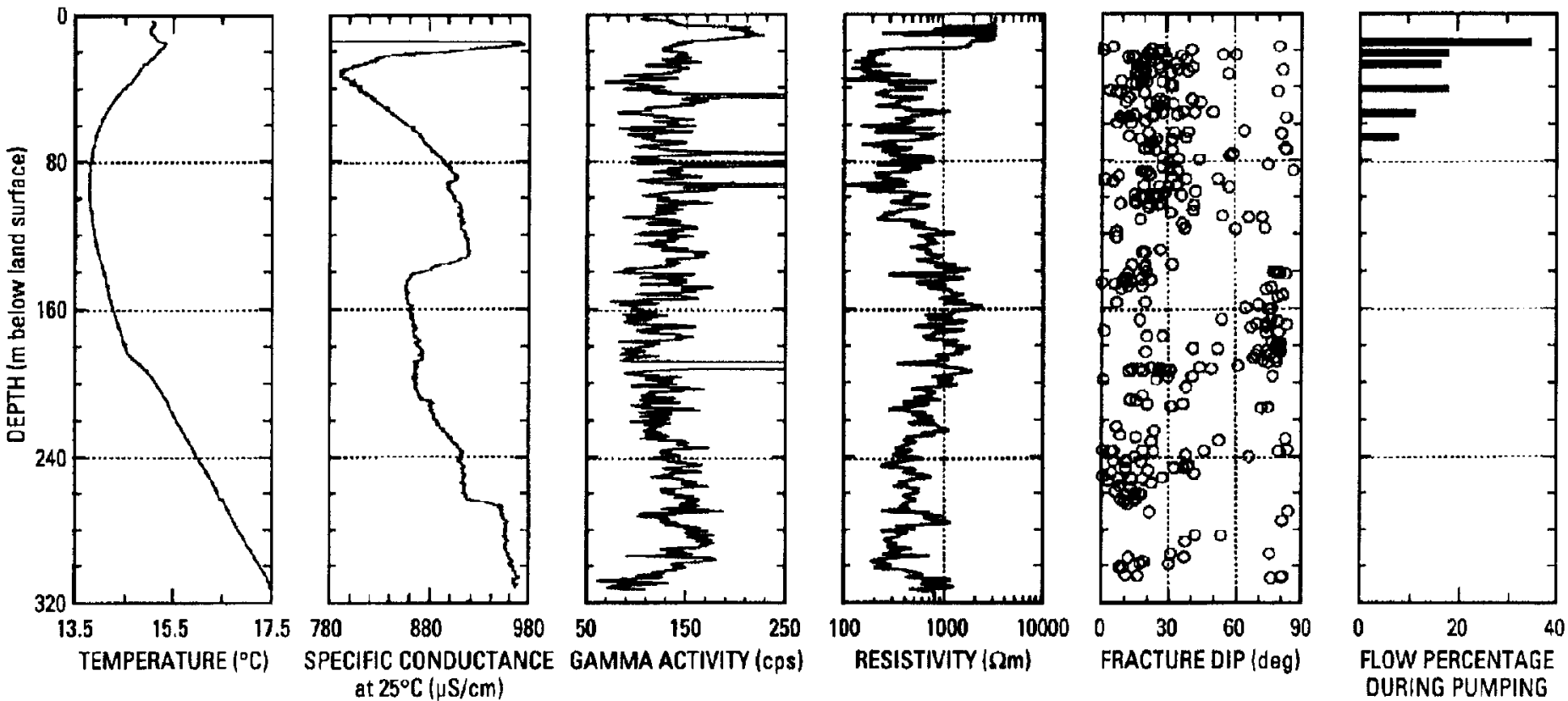

Figure 6. Composite of selected logs from well 64.
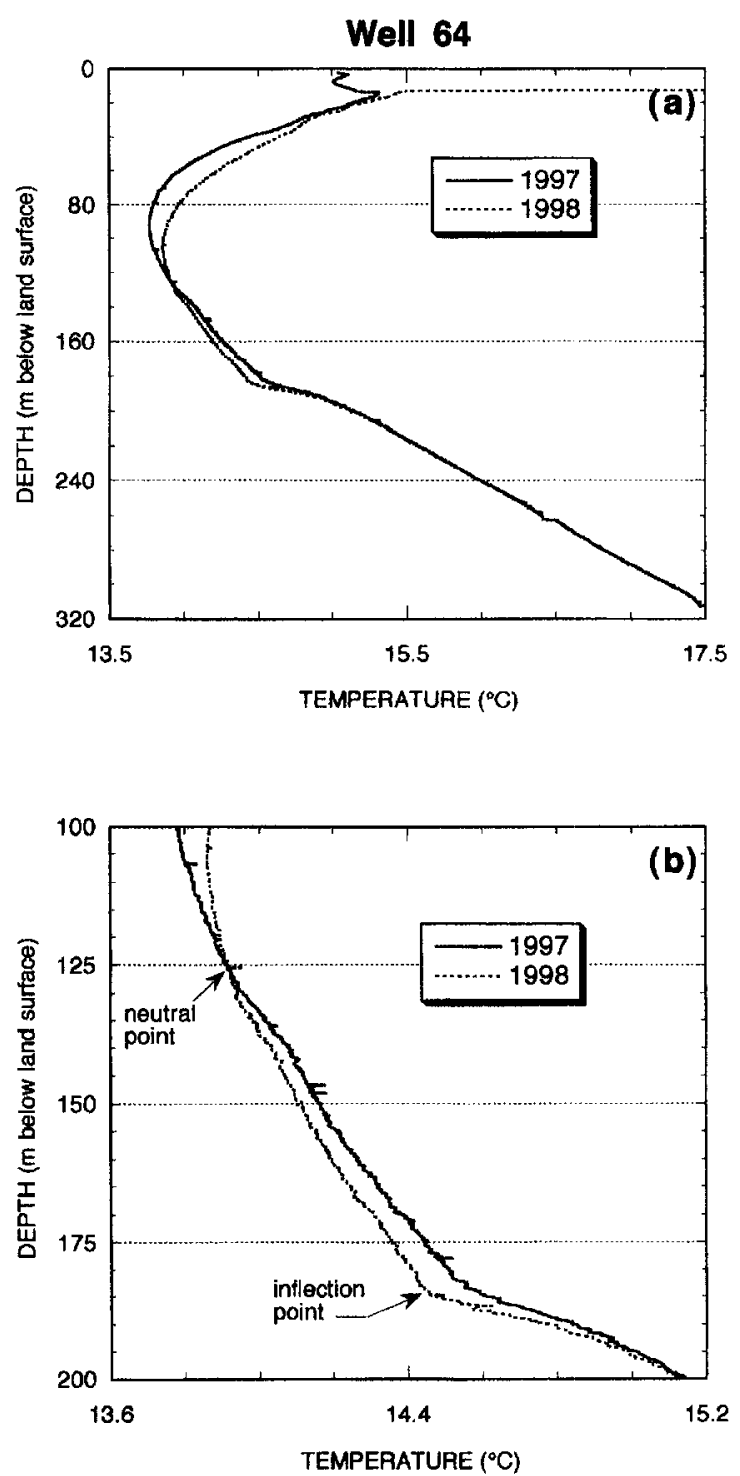

Figure 7. Comparison of temperature logs from well 64 (with expanded view) recorded in 1997 and in 1998. nant $(\lambda=0.80)$. Water movement through the subsurface is controlled by a subset of these bedding-plane partings and most of this flow is confined to the upper few tens of meters.

\section{Deep Well}

The log composite obtained for well 64 is presented in Figure 6. Above a depth of $120 \mathrm{~m}$, the logs for this well are similar to those from the six shallow wells previously described. Thus, the same general conclusions for units in the 0 to $120 \mathrm{~m}$ depth range continue to be valid: (1) Shale beds appear as sharp spikes in the gamma log; (2) the gamma and resistivity logs exhibit an inverse relation representing lithologic variations; (3) most fractures are gently dipping bedding-plane partings; and (4) permeable zones identified during pumping are highly transmissive near the surface but diminish rapidly and can no longer be detected below about $70 \mathrm{~m}$. Because this well was drilled to a depth of $335 \mathrm{~m}$, it projects a view of the formation that extends approximately $215 \mathrm{~m}$ below that furnished by the six shallow wells. It also provides a view of the Newark Basin that continues roughly $270 \mathrm{~m}$ below that investigated by Morin et al. (1997). Several notable hydrogeologic characteristics emerge from this deeper perspective of the aquifer that enhance significantly the diagnostic value of these geophysical data.

A dense sandstone unit is identified from the deeper logs that is about $60 \mathrm{~m}$ thick (approximately 125 to $185 \mathrm{~m}$ depth) and is characterized by generally higher resistivity values and a higher concentration of steeply dipping fractures. The upper and lower contacts of this interval coincide with shifts in the fluid-property logs (a specific conductance change at $125 \mathrm{~m}$ and a temperature change at $185 \mathrm{~m}$ ), indicating fluid movement along the boundaries of the sandstone unit but not within it. This observation is supported by a comparison of two temperature logs that were recorded in early June of successive years (Figure 7) using the same logging tool and run at the same logging speed. A thermal neutral point at a depth of about $125 \mathrm{~m}$ and an inflection point at approximately $185 \mathrm{~m}$ identify the zones of fluid exchange in the well. Although the fluid-property perturbations infer fluid movement and the presence of permeable fractures, the associated transmissivities at these depths are apparently below the resolution limit of the heat-pulse flowmeter 


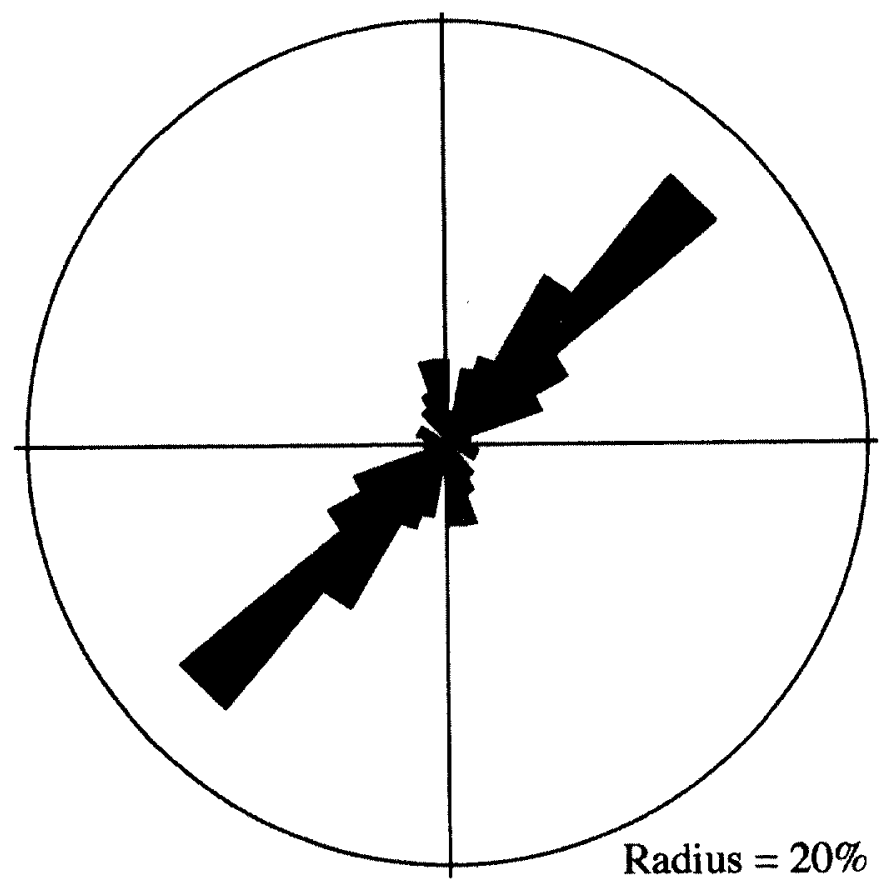

all fractures below $125 \mathrm{~m}$

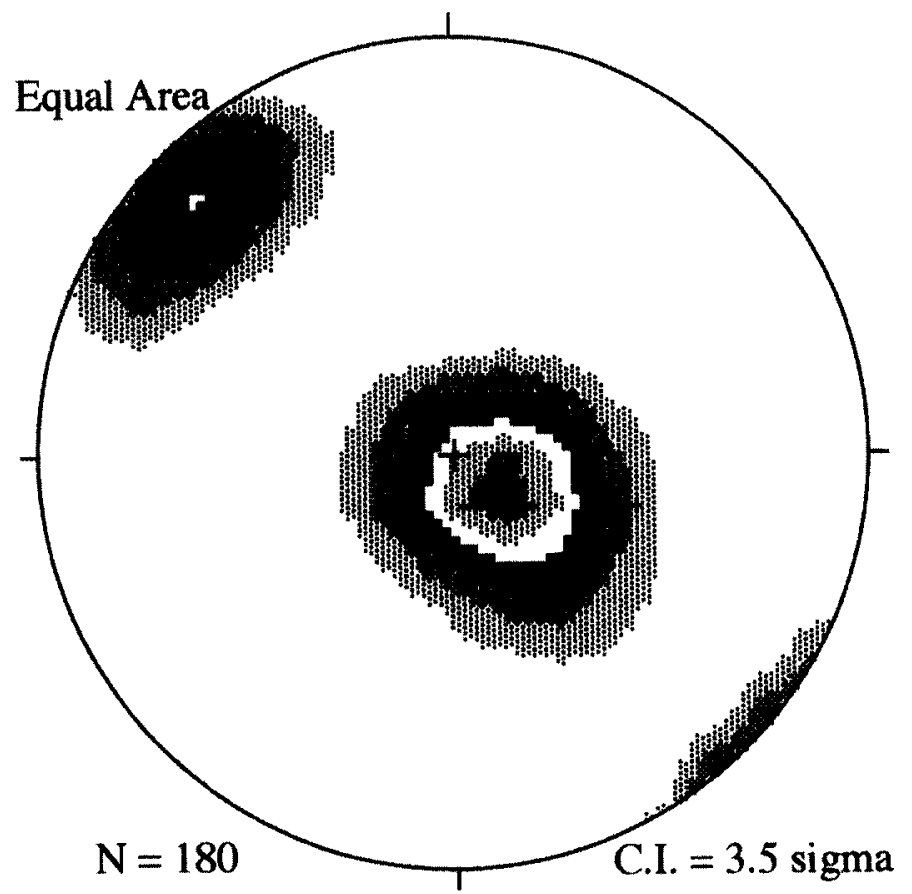

Figure 8. Rosette and equal-area stereographic diagrams representing fracture orientations in well 64 below $125 \mathrm{~m}(\mathrm{~N}=$ number of fractures; C.I. = contour interval).

because no flow was detected under static conditions or during pumping. The lower contact of this unit is truncated by a shale bed (large gamma spike) and is also delineated by the appearance of a linear gradient in the 1997 temperature log that is reproduced in the 1998 log. This signals the lower hydrologic boundary of the aquifer and no evidence of ground water movement is found below it.

Electrical resistivities within this dense, low-transmissivity sandstone are greater than $1000 \mathrm{ohm}-\mathrm{m}$ (Figure 6). The highly resistive nature of this interval is enhanced by the presence of subvertical fractures that, unlike subhorizontal fractures, typically aug-

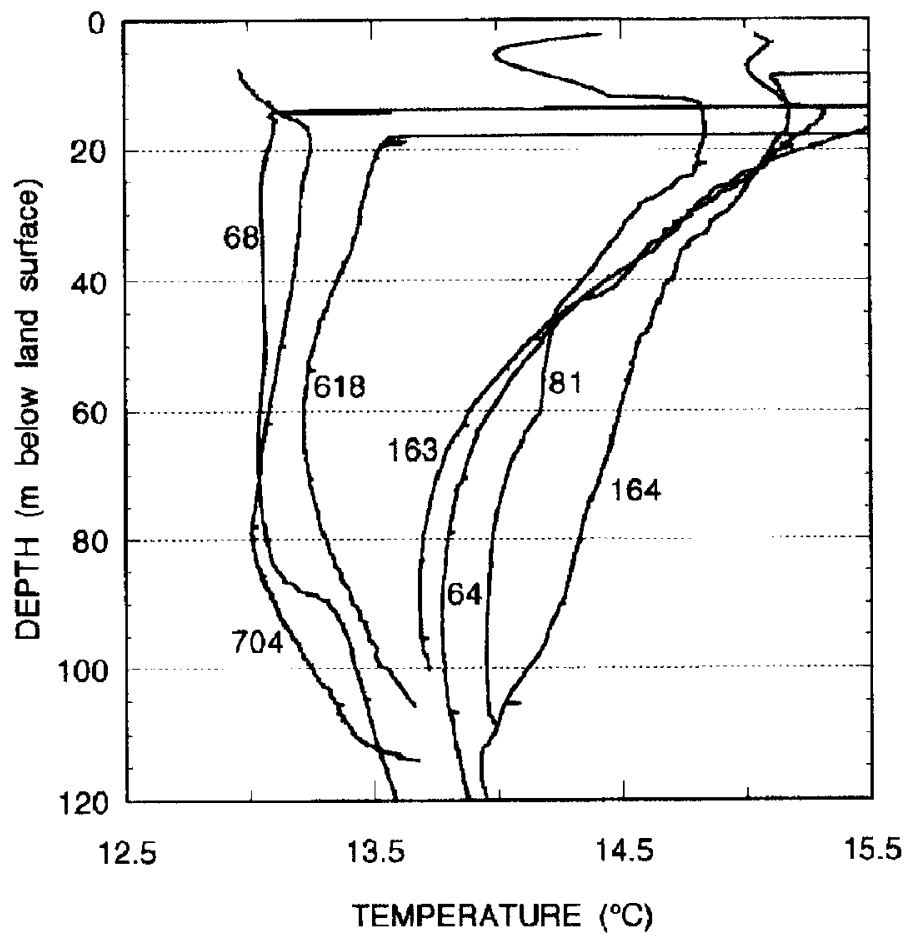

Figure 9. Collection of temperature logs for all seven wells above $120 \mathrm{~m}$.

ment the electrical resistivity of a rock mass by retarding the natural current flowpaths from the logging tool through the surrounding formation (Pezard 1990). Televiewer images of such a feature detected in well 64 are shown in Figure 4b; note the increase in sinusoidal amplitude compared with the shallow dipping bedding planes in Figure $4 \mathrm{a}$. A rose diagram and a stereographic plot of poles to fracture planes identified below $125 \mathrm{~m}$ in well 64 are presented in Figure 8; these plots clearly identify two orthogonal fracture sets, with their corresponding eigenvalues and eigenvectors listed in Table 2.

The stereographic data illustrate that gently dipping beddingplane partings continue to be prevalent below $125 \mathrm{~m}$, but that a significant population of high-angle fractures striking northeast-southwest and dipping steeply (77 degrees) to the southeast is also present. These high-angle features are directly associated with the appearance of dense sandstones and are considered to be paleovertical fractures, aligned with the general orientation of the Newark Basin and formed normal to originally horizontal bedding. Fractures such as these are common in the rocks of the Hartford and Newark basins (Stone et al. 1996; Vecchioli et al. 1969); they developed early in the history of basin evolution while rifting continued and the more competent, coarser-grained beds responded brittlely to extensional stress (Eardley 1962). The numerous steeply dipping fractures identified by Morin et al. (1997) across the upper $50 \mathrm{~m}$ at their study site in New Jersey are indicative of the more dispersed nature of sandstone units in that part of the Newark Basin.

About 65 of these high-angle features were identified, but we suspect that numerous others went undetected because of the inherent sampling bias associated with the identification of subvertical planes by means of a vertical borehole. The probability of intersecting a subhorizontal feature with a vertical borehole is high, whereas the probability of intersecting a near-vertical one is low. To account for this deficiency, a geometric correction factor based on dip angle may be applied to fracture populations (Terzaghi 1965). The number of fractures having a dip angle $\theta$ is multiplied by a weighting factor of $[1 / \cos \theta]$ to arrive at the probable number of frac- 


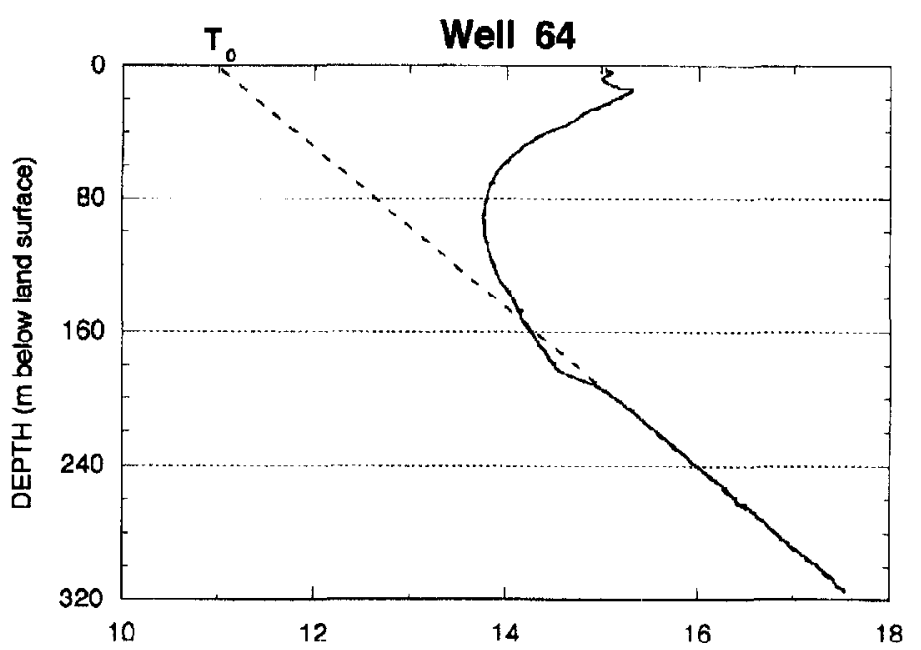

Figure 10. Projection to surface of linear geothermal gradient in well $64\left(\mathrm{~T}_{0}=11.0^{\circ} \mathrm{C}\right.$; refer to Equation 1$)$.

tures present. In this case, the 65 or so steeply dipping fractures represent a probable population of approximately 280 .

\section{Ground-Surface Warming}

The temperature logs across the 0 to $120 \mathrm{~m}$ depth range of the aquifer in all seven wells are displayed in Figure 9; most of these traces exhibit a common concave form with respect to depth. After initially examining the temperature profiles from only the shallow wells, we postulated that this characteristic shape could perhaps represent a cold water front produced by horizontal water movement and recharge through the aquifer. This phenomenon has been identified and modeled by several investigators (e.g., Cartwright 1971; Ziagos and Blackwell 1986; Lu and Ge 1996) and may be relevant to hydrologic conditions in this area. However, careful examination of the vertical extension of the temperature profile provided by well 64 suggests another interpretation that is supported by the deeper linear gradient, the regional geothermal heat budget, and the historical context of land use near Lansdale.

Lachenbruch (1957) recognized the effects of prolonged surficial heating on the subsurface geological environment; numerous scientists have since exploited related concepts to infer consequences of climate change (e.g., Beck 1992; Chisholm and Chapman 1992; Guillou-Frottier et al. 1998). The temperature logs analyzed in such climate studies exhibit concave shapes reminiscent of those from the shallow Lansdale wells displayed in Figure 9. Roy et al. (1972) reported a similar thermal pattern in a drillhole on the Harvard University campus in Massachusetts, but attributed the distinctive concave profile to an increase of the ground-surface temperature caused by building construction. Further evidence of this phenomenon has been reported by Paulachok (1991) from temperature data recorded in nearby Philadelphia, Pennsylvania. These findings demonstrated that industrialization and deforestation can produce a relatively sudden increase in the local surface temperature that is subsequently transmitted into the earth. Recently, Steitz and Tyson (1998) have reported on a study undertaken to assess the environmental impact of these "urban heat islands." Because the borough of Lansdale underwent substantial urbanization at the turn of the century, we now consider how such activity could be responsible for producing the observed temperature logs.

We begin by assuming a thermally homogeneous, semi-infinite half space where heat is transferred in one direction by conduction
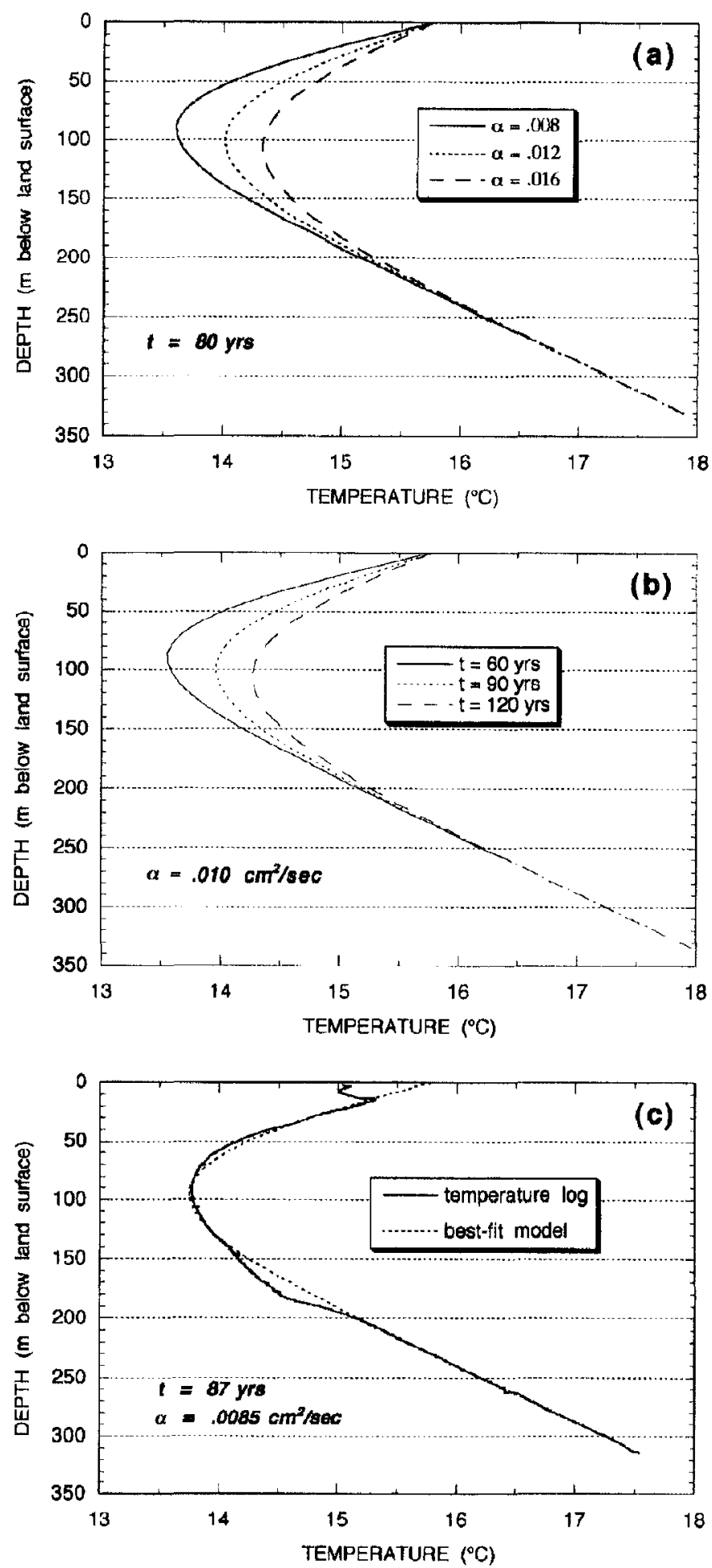

Figure 11. Theoretical curves developed from Equation 1 illustrating transient conduction of heat into the ground. (a) Temperature profiles after 80 years with varying thermal diffusivities; (b) temperature profiles for various time periods with constant thermal diffusivity of $.010 \mathrm{~cm}^{2} / \mathrm{sec}$; (c) best-fit theoretical match to actual temperature $\log$ recorded in well 64

only. If a stepwise temperature perturbation is suddenly introduced at the surface, a thermal wave is generated that propagates vertically into the medium. The transient distribution of temperature as a function of depth, $T(z, t)$, can be expressed as the superposition of a linear background temperature gradient and the effects of this surficial temperature perturbation (Carslaw and Jaeger 1978): 


$$
T(z, t)=T_{0}+\beta z+\Delta T_{0} \operatorname{erfc}\left[-\frac{z}{\sqrt{4 \alpha t}}\right]
$$

where $\mathrm{z}=$ depth below land surface, $\mathrm{t}=$ time since onset of temperature shift at surface, $T_{0}=$ initial, undisturbed surface temperature, $\beta=$ geothermal gradient, $\Delta \mathrm{T}_{0}=$ temperature shift at surface for $\mathrm{t}>0, \alpha=$ thermal diffusivity of formation, and erfc $=$ complementary error function where the term in brackets is dimensionless.

The background geothermal gradient, $\beta$, is estimated directly from the slope of the temperature log for well 64 below $200 \mathrm{~m}$, where the temperatures likely have not been disturbed by fluid movement or recent surficial perturbations. This natural gradient is calculated to be $20.9^{\circ} \mathrm{C} / \mathrm{km}$ and its extrapolation to the surface yields a value of $11.0^{\circ} \mathrm{C}$ for the initial surface temperature, $\mathrm{T}_{0}$ (Figure 10 ). This estimate is in excellent agreement $\left( \pm 0.5^{\circ} \mathrm{C}\right)$ with long-term temperature data recorded at nearby weather stations (NOAA 1993; Greenman 1955). The thermal diffusivity, $\alpha$, of sedimentary rocks at temperatures between $10^{\circ} \mathrm{C}$ and $20^{\circ} \mathrm{C}$ is not extensively known, but available estimates reported by Birch (1942) and by Roy et al. (1981) fall mostly in the range of .005 to $.013 \mathrm{~cm}^{2} / \mathrm{sec}$.

Two series of type curves are developed from Equation 1 by substituting several values for the parameters time, $t$, and diffusivity, $\alpha$, in order to evaluate the sensitivity of the transient temperature profiles to these variables. In Figure $11 \mathrm{a}$, the time $\mathrm{t}$ since the onset of the surface temperature shift $\left(\Delta \mathrm{T}_{0}=4.80^{\circ} \mathrm{C}\right)$ is held constant at 80 years and curves corresponding to different values of thermal diffusivity are plotted. In Figure $11 \mathrm{~b}, \alpha$ is held constant at $.010 \mathrm{~cm}^{2} / \mathrm{sec}$ and $t$ is varied from 60 to 120 years. A least-squares routine was used to generate a best-fit theoretical simulation of the 1997 temperature $\log$ for well 64; an optimal match to the observed data is achieved when $\alpha=.0085 \mathrm{~cm}^{2} / \mathrm{sec}$ and $\mathrm{t}=87$ years (Figure $11 \mathrm{c}$ ).

The values of thermal diffusivity selected for Figure 11 a were arbitrarily chosen to represent materials having low $(\alpha=.008$ $\left.\mathrm{cm}^{2} / \mathrm{sec}\right)$, normal $\left(\alpha=.012 \mathrm{~cm}^{2} / \mathrm{sec}\right)$, and high $\left(\alpha=.016 \mathrm{~cm}^{2} / \mathrm{sec}\right)$ thermal transport properties. The high range of thermal diffusivities is appropriate for sedimentary rocks with large concentrations $(>20 \%$ ) of quartz. The curve-matching exercise yielded an estimate of thermal diffusivity for the rocks in the Lansdale area that lies in the low range, which is consistent with a conductive gradient of 20 to $21^{\circ} \mathrm{C} / \mathrm{km}$ and a regional heat flow of roughly $40 \mathrm{~mW} / \mathrm{m}^{2}$ for this part of southeastern Pennsylvania (Lachenbruch and Sass 1977). The ratio of this relatively low heat-flow value to the thermal gradient infers a correspondingly low thermal conductivity that, in turn, indicates a low thermal diffusivity. Thus, our estimate for $\alpha$ of .0085 $\mathrm{cm}^{2} / \mathrm{sec}$ from curve matching is realistic for this geologic environment. Slight departures between the modeled and measured curves (Figure 11c) are due primarily to fluid movement and, to a lesser extent, variability in the thermal and other physical properties of the sedimentary units. Short of complex numerical simulations that require detailed knowledge of the spatial variability of these deposits, this simple model that assumes a homogeneous medium with uniform thermal properties throughout seems to provide a reasonable first-order approximation.

The temperature logs that display marked concave shapes and a significant warming of the surface (wells 64, 163, and 81 in Figure 9) are from wells located in the central downtown district near heated buildings, asphalt streets, and paved parking lots. A few logs in Figure 9, such as those for wells 618 and 704, exhibit a less dramatic concave shape and are generally cooler. These wells are located in fields where trees and other vegetation may dampen solar exposure. The logs that do not display any semblance of a concave form have been highly disturbed by fluid flow in the wellbore and, consequently, any clear evidence of surficial warming has been lost. The successful application of this simple analytical temperature model implies that human activity and reduction of vegetation at the turn of the century has caused significant surficial warming that is evident some 80 to 90 years later. It also rejects the hypothesis that the concave temperature logs are a manifestation of horizontal cold water recharge beneath Lansdale.

A systematic warming of the upper $80 \mathrm{~m}$ near most well sites has implications for the local fluid-transport properties of the aquifer because almost all detectable flow is confined to this upper zone. Constantz et al. (1994) recognized this type of "climatic" influence by considering the effect of stream temperature on the hydraulic conductivity of the underlying streambed. The hydraulic conductivity is a function of several parameters, some of which are temperature-sensitive (Muskat 1937):

$$
\mathrm{K}=\mathrm{kg} \frac{\rho}{\eta}
$$

where $\mathrm{K}=$ hydraulic conductivity $(\mathrm{cm} / \mathrm{sec}), \mathrm{k}=$ intrinsic permeability $\left(\mathrm{cm}^{2}\right), \mathrm{g}=$ gravitational constant $\left(\mathrm{cm} / \mathrm{sec}^{2}\right), \rho=$ fluid density $\left(\mathrm{g} / \mathrm{cm}^{3}\right)$, and $\eta=$ fluid dynamic viscosity $(\mathrm{g} / \mathrm{cm}-\mathrm{sec})$. The density and viscosity both decrease with increasing temperature; however, $\eta$ decreases at a faster rate. If we assume that the predominant transmissive zone in this aquifer has undergone an average temperature increase equal to about half of the stepwise temperature shift at the surface $\left(\Delta \mathrm{T}_{0} / 2\right)$, then it has warmed up by $2.40^{\circ} \mathrm{C}$ over the past 90 years or so. In response to this temperature change, the hydraulic conductivity of this zone should have increased by almost $10 \%$ over the same time period (Equation 2).

\section{Summary and Discussion}

Results of this field investigation in Lansdale, Pennsylvania, illustrate the value and utility of using geophysical logs to characterize the hydrogeologic properties of a sedimentary-rock aquifer. The advantages of drilling one deep well as part of the general surveillance program are also made evident. This deeper, more comprehensive view of the ground water system provides the key evidence for historical surficial warming, thereby discrediting an alternative hypothesis that implicated cold, horizontal recharge as the source for observed concave temperature profiles. The logs from the deep well also identify a stratigraphic unit that serves as the lower hydrologic boundary and enables the aquifer to be separated into two distinct structural domains at this well location. Integrating this information with previous studies (Morin et al. 1997) refines our general conceptual understanding of the hydrogeology of the Newark Basin.

The inverse correlation between electrical resistivity and gamma activity is particularly good at this site, enhanced by the apparent paucity of potassium feldspar in sandstone units, and fine-scale lithologic information can be extracted from these two complementary logs. Fluid flow and the primary hydrologic characteristics of this aquifer are controlled by fractures, and almost 900 of them are identified from inspection of the digital televiewer logs. The predominant fracture strike is $N 46^{\circ} \mathrm{E}$, a bearing that is coincident with surface lithologic expressions and the general orientation of the Newark Basin. The vast majority of fractures above $125 \mathrm{~m}$ are bedding-plane partings that dip at about 11 degrees to the northwest, whereas a deeper structural domain penetrated by well 64 is delineated by the appearance of a subvertical fracture popu- 
lation. This latter fracture set is isolated within a dense, low-transmissivity sandstone unit and is orthogonal to the bedding planes, sharing the same strike but dipping steeply to the southeast. Flowmeter measurements indicate that productivity is predominantly confined to the upper $80 \mathrm{~m}$ of this aquifer and, correspondingly, most ground water flow is channelled through the shallow-dipping features. Michalski and Britton (1997) conducted field investigations in other parts of the Newark Basin and similarly found the principal fluid pathways to be shallow bedding planes.

Conceptual flow models (Michalski 1990), field observations (Houghton 1990; Carleton et al. 1999), and geophysical measurements (Morin et al. 1997) applied to several study areas in the Newark Basin also point to the presence of a subvertical fracture population that is interspersed among the subhorizontal bedding planes. These fractures appear mostly in dense sandstone units and may represent the mechanical failure of brittle rocks in response to basin extension. Thus, although fluid flow is primarily controlled by fractures, fracture type and orientation are related to lithology. At the New Jersey site investigated by Morin et al. (1997), steeply dipping fractures contributed to the overall hydrologic response of the aquifer and introduced an important degree of horizontal anisotropy into the system. Conversely, the site at Lansdale revealed few steeply dipping fractures in the upper $125 \mathrm{~m}$; these fractures are evident only at greater depths and do not contribute significantly to ground water movement. Consequently, subsurface fluid flow in the Lansdale area is presumed to be a function of the orientation of the bedding-plane partings and is not obfuscated by the superposition of competing fracture populations or networks.

Measurement of transmissivity at multiple locations and depths indicates that the formation is highly heterogeneous within any individual borehole, but if viewed at a larger scale, the shallow $(<125 \mathrm{~m})$ system is relatively homogeneous. The lower contact of the deep sandstone unit is truncated by a shale bed that marks the lowermost extent of the aquifer at a depth of about $190 \mathrm{~m}$. Below this depth, bedding-plane partings once again emerge as the dominant fracture type, the temperature log reflects the conductive geothermal gradient for the region, and the gradual transition into the low-productivity Lockatong Formation continues.

\section{Acknowledgments}

We are grateful to the North Penn Water Authority and several private well owners for allowing us access to their wells.

\section{References}

Archie, G.E. 1942. The electrical resistivity $\log$ as an aid in determining some reservoir characteristics. Trans., American Institute of Mining, Metallurgical and Petroleum Engineers 146, 54-62.

Beck, A.E. 1992. Inferring past climate change from subsurface temperature profiles: Some problems and methods. Global and Planetary Change 6, no. 2/4: 73-80.

Birch, F. 1942. Thermal conductivity and diffusivity. In Handbook of Physical Constants, ed. F. Birch, J.F. Schairer, and H.C. Spicer. Special Paper no. 36: 243-266. Boulder, Colorado: Geological Society of America.

Carleton, G.B., C. Welty, and H.T. Buxton. 1999. Design and analysis of tracer tests to determine effective porosity and dispersivity in fractured sedimentary rocks, Newark Basin, New Jersey. U.S. Geological Survey Water Resources Investigations Report 98-4126A.

Carslaw, H.S., and J.C. Jaeger. 1978. Conduction of Heat in Solids, 2nd ed. London: Oxford University Press.

Cartwright, K. 1971. Redistribution of geothermal heat by a shallow aquifer. Geological Society of America Bulletin 82, 3197-3200.

CH2M Hill Inc. 1991. North Penn Area 6 Phase II RI/FS and FFS Work Plan, Work Assignment no. 04-3LW9.0, contract no 68-W8-0090, prepared for the U.S. Environmental Protection Agency, June 1991.
Philadelphia, Pennsylvania.

Chisholm, T.J., and D.S. Chapman. 1992. Climate change inferred from analysis of borehole temperatures: An example from western Utah. J. Geophysical Research 97, no. B 10: 14,155-14,175.

Conaway, J.G., and A.E. Beck. 1977. Fine-scale correlation between temperature gradient logs and lithology. Geophysics 42, no. 7: 14011410.

Conger, R.W. 1999. Evaluation of geophysical logs at North Penn Area 6 Superfund Site, Lansdale, Montgomery County, Pennsylvania. U.S. Geological Survey Open-File Report 99-27l.

Constantz, J., C.L. Thomas, and G. Zellweger. 1994. Influence of diurnal variations in stream temperature on streamflow loss and groundwater recharge. Water Resources Research 30, no. 12: 3253-3264.

Drury, M.J. 1989. Fluid flow in crystalline crust: Detecting fractures by temperature logs. In Hydrogeological Regimes and Their Subsurface Thermal Effects, ed. A.E. Beck, G. Garven, and L. Stegena. Geophysical Monograph 47, IUGG vol. 2: 129-135. Washington, D.C.: Geophysical Union.

Drury, M.J., A.M. Jessop, and T.I. Lewis. 1984. The detection of groundwater flow by precise temperature measurements in boreholes. Geothermics 13, no. 3: 163-174.

Eardley, A.J. 1962. Structural Geology of North America, 2nd ed. New York: Harper and Row.

Fisher, E.H., G. Lewis, and R. Embleton. 1987. Statistical Analysis of Spherical Data. London: Cambridge University Press.

Froelich, A.J., and G.R. Robinson Jr. (eds.). 1988. Studies of the early Mesozoic basins of the eastern United States. U.S. Geological Survey Bulletin 1776.

Goode, D.J, and L.A. Senior. 1998. Review of aquifer test results lor the Lansdale area, Montgomery County, Pennsylvania, 1980-95. U.S. Geological Survey Open-File Report 98-294

Greenman, D.W. 1955. Ground water resources of Bucks County, Pennsylvania. Pennsylvania Geological Survey, Fourth Series, Bulletin W11. Harrisburg, Pennsylvania.

Guillou-Frottier, L., J.-C. Mareschal, and J. Musset. 1998. Ground surface temperature history in central Canada inferred from 10 selected borehole temperature profiles. $J$. Geophysical Research 103, no. B4: 7385-7397.

Hess, A.E. 1986. Identifying hydraulically conductive fractures with a slowvelocity borehole flowmeter. Canadian Geotechnical J. 23, no. 1: 6978.

Houghton, H.F. 1990 . Hydrogeology of the early Mesozoic rocks of the Newark Basin, New Jersey. In Proceedings, Aspects of Groundwater in New Jersey, Geological Assc. of New Jersey 7th Annual Meeting, Kean College of New Jersey, Union, New Jersey, ed. R.L. Kroll and J.O. Brown, E1-E36. Trenton, New Jersey: Geological Association of New Jersey.

Lachenbruch, A.H. 1957. Three-dmensional heat conduction in permafrost beneath heated buildings. U.S. Geological Survey Bulletin 1052-B.

Lachenbruch, A.H., and J.H. Sass. 1977. Heat flow in the United States and the thermal regime of the crust. In The Earth's Crust, ed. J.G. Heacock, Monograph 20, 626-675. Washington, D.C.: American Geophysical Union.

Long, J.C.S., A. Aydin, S.R. Brown, H.H. Einstein, K. Hestir, P.A. Hsieh, L.R. Myer, K.G. Nolte, D.L. Norton, O.L. Olsson, F.L. Paillet, J.L. Smith, and L. Thomsen. 1996. Rock Fractures and Fluid Flow: Contemporary Understanding and Applications. Washington, D.C.: National Academy Press.

Longwill, S.M., and C.R. Wood. 1965. Ground-water resources of the Brunswick Formation in Montgomery and Berks Counties, Pennsylvania. Pennsylvania Topographic and Geologic Survey Water Resource Report 22. Harrisburg, Pennsylvania.

Lu, N., and S. Ge. 1996. Effect of horizontal heat and fluid flow on the vertical temperature distribution in a semiconfining layer. Water Resources Research 32, no. 5: 1449-1453.

Lyttle, P.T., and J.B. Epstein. 1987. Geologic map of the Newark $1^{\circ} \times 2^{\circ}$ quadrangle, New Jersey, Pennsylvania, and New York. U.S Geological Survey Miscellaneous Investigations Series Map I-1715, 2 pl., scale 1:250,000.

Mardia, K.V. 1972. Statistics of Directional Data. London: Academic Press.

Michalski, A. 1990. Hydrogeology of the Brunswick (Passaic) Formation and implications for ground water monitoring practice. Ground Water Monitoring Review X., no. 4: 134-143. 
Michalski, A., and R. Britton. 1997. The role of bedding fractures in the hydrogeology of sedimentary bedrock-Evidence from the Newark Basin, New Jersey. Ground Water 35, no. 2: 318-327.

Molz, F.J., R.H. Morin, A.E. Hess, J.G. Melville, and O. Güven. 1989. The impeller meter for measuring aquifer permeability variations: Evaluation and comparison with other tests. Water Resources Research 25, no. 7: 1677-1683.

Morin, R.H., A.E. Hess, and F.L. Paillet. 1988. Determining the distribution of hydraulic conductivity in a fractured limestone aquifer by simultaneous injection and geophysical logging. Ground Water 26, no. 5: 587-595.

Morin, R.H., G.B. Carleton, and S. Poirier. 1997. Fractured-aquifer hydrogeology from geophysical logs; The Passaic Formation, New Jersey. Ground Water 35, no. 2: 328-338.

Muskat, M. 1937. The Flow of Homogeneous Fluids Through Porous Media. New York: McGraw-Hill.

National Oceanic and Atmospheric Administration (NOAA). 1993. Climatological data annual summary, Pennsylvania, 98, no. 13. Asheville, North Carolina: NOAA.

Olsen, P.E. 1980. The latest Triassic and early Jurassic formations of the Newark Basin (eastern North America, Newark Supergroup): Stratigraphy, structure, and correlation. New Jersey Academy of Science Bulletin 25, 25-51.

Olsen, P.E. 1988. Continuity of strata in the Newark and Hartford Basins. In Studies of the Early Mesozoic Basins of the Eastern United States, ed. A.J. Froelich and G.R. Robinson Jr., 6-18. U.S. Gcological Survey Bulletin 1776.

Parker, R.A., H.F. Houghton, and R.C. McDowell. 1988. Stratigraphic framework and distribution of early Mesozoic rocks of the Northern Newark Basin, New Jersey and New York. In Studies of the Early Mesozoic Basins of the Eastern United States, ed. A.J. Froelich and G.R. Robinson Jr., 31-39. U.S. Geological Survey Bulletin 1776.

Paulachok, G.N. 1991. Geohydrology and ground-water resources of Philadelphia, Pennsylvania. U.S. Geological Survey Water-Supply Paper 2346.

Pezard, P.A. 1990. Electrical properties of mid-ocean ridge basalt and implications for the structure of the upper oceanic crust in Hole 504B. $J$. Geophysical Research 95, no. B6: 9237-9264.
Roy, R.F., E.R. Decker, D.D. Blackwell, and R. Birch. 1968. Heat flow in the United States. J. Geophysical Research 73, no. 16: 5207-5221.

Roy, R.F., D.D. Blackwell, and E.R. Decker. 1972. Continental heat flow. In The Nature of the Solid Earth, ed. E.C. Robertson, 506-543. New York: McGraw-Hill.

Roy, R.F., A.E. Beck, and Y.S. Touloukian. 1981. Thermophysical properties of rocks. In Physical Properties of Rocks and Minerals, McGraw-Hill/CINDAS Data Series on Material Properties, vol. II2, 409-502, ed. Y.S. Touloukian, W.R. Judd, and R.F. Roy. New York: McGraw-Hill.

Schlische, R.W. 1992. Structural and stratigraphic development of the Newark extensional basin, eastern North America: Evidence for growth of the basin and its bounding structures. Geologic Society of America Bulletin 104, 1246-1263.

Steitz, D.E., and T. Tyson. 1998. Some of the country's "hottest" cities using early results from a NASA study to improve urban planning and environment. Marshall Space Flight Center News Release 98-209.

Stone, J.R., P.M. Barlow, and J.J. Starn. 1996. Geohydrology and conceptual model of a ground-water flow system near a Superfund site in Cheshire, Connecticut. U.S. Geological Survey Open-File Report 96-162.

Terzaghi, R. 1965. Sources of error in joint surveys. Geotechnique 15, 287-304.

Vecchioli, J., L.D. Carswell, and H.F. Kasabach. 1969. Occurrence and movement of ground water in the Brunswick Shale at a site near Trenton, New Jersey. U.S. Geological Survey Prof. Paper 650-B; B 154-B157.

Weddle, T.K., and J.F. Hubert. 1983. Petrology of upper Triassic sandstones of the Newark Supergroup in the northern Newark, Pomperaug, Hartford, and Deerfield Basins. Northeastern Geology 5, 8-22.

Williams, J.H., W.W. Lapham, and T.H. Barringer. 1993. Application of electromagnetic logging to contamination investigations in glacial sand-and-gravel aquifers. Ground Water Monitoring and Remediation 13, no. 1: 129-138

Zemanek, J., E.E. Glenn, L.J. Norton, and R.L. Caldwell. 1970. Formation evaluation by inspection with the borehole televiewer. Geophysics 35, 254-269.

Ziagos, J.P., and D.D. Blackwell. 1986. A model for the transient temperature effects of horizontal fluid flow in geothermal systems. $J$. Volcanology and Geothermal Research 27, 371-397.

\section{AGWSE Corporate Members:}

Don't miss out!

\section{Did you knOW that a a AGWSE corporate menthesship allows three individual to be} listed as NGWA members? This membership allows for a primary contact and two additional persons to be listed under the membership. If you don't have three members on your corporate membership, you're missing out on valuable benefits and resources from NGWA!

\section{Take a moment to revieW your AGWSE corporate membership and}

be sure you are taking full advantage of your membership. If you need assistance or would like to know who is identified on your membership, contact NGWA Customer Service or the Membership Department at 800-551-7379.

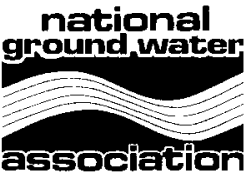

